\title{
Optimisation of stoping parameters for a cut and fill stope at Chikla mine of MOIL Ltd: A case study
}

\author{
GD Raju, Prasnna Jain, V Venkateswarlu and A Rajan Babu \\ National Institute of Rock Mechanics \\ Kolar Gold Fields, India \\ guntumadugu.raju@mail.mcgill.ca
}

\author{
GG Manekar \\ MOIL Ltd \\ Nagpur, India
}

\begin{abstract}
MOIL Ltd. (formerly Manganese ore India limited) operates 10 mines. Out of this 7 mines are underground. Chikla mine is one of the underground mines. The mining method employed here is horizontal cut \& Fill. The present paper describes the studies conducted to optimize the stoping parameters for better safety and productivity at Chikla mine. Support requirements for the proposed stope block between Ch-2365 and Ch-2425 from level 3 to level 2 is evaluated through the empirical methods and the stability of the crown pillar and the support behaviour is studied with numerical modeling. It was found that the wall rocks and the ore body have distinct strength properties and the rock mass falls in to good and fair categories. Two most popular rock mass classification systems were used for estimating the support requirements for the proposed stope block. A two dimensional finite deference code was used for numerical modeling. This paper presents the geotechnical parameters of the study area and the empirical support design and the numerical modeling results for the proposed stoping block at Chikla Mine.
\end{abstract}

Keywords - cut and fill method; numerical model; stoping; supports; crown pillar curious

\section{INTRODUCTION}

MOIL ltd (formerly Manganese ore India limited) operates 10 mines. Out of this 7 mines are underground. Chikla mine is one of the underground mines. The mining method employed here is horizontal cut \& Fill. MOIL Ltd initiated a project to conduct the studies to optimize the stoping parameters for better safety and productivity at Chikla mine. The mineralization of manganese ore in this mine is in the in the form of minerals Braunite, Gondite associated with muscovite schist/quartz muscovite schist[1]. The mining method followed in the mine is cut and fill method of mining with a pre support of $12 \mathrm{~m}$ long cablebolts. The main objective of this study is to design and optimize the stoping parameters.

\section{GEOLOGY}

Chikla Mine (Latitude: $21^{\circ} 31^{\prime}$ North, Longitude: $79^{\circ} 45^{\prime}$ East) is located in the north eastern part of Bhandara district, Maharashtra state and falls in the Survey of India Toposheet
No. 55O/14. The geological formations of the area belong to Mansar Formation of Saurar Group.

\section{A. Project Geology}

In Chikla mines the manganese ore zone occurs at the contact of mica schist of Mansar Formation and quartz mica schist of Sitasaongi Formation of Sausar Group. The manganese ore body is controlled by the structure of the area. The manganese ore body occurs at the core of the plunging synform of the area. The manganese ore is mined along the trace of the axial plain of the synform. The axial plane of these folds strikes in almost East-West direction with $70^{\circ}$ dip due south. Since the litho units are isoclinally folded, the repetition of hangwall and footwall strata is common in the area. The Ore body strikes almost East-West and dips due south with moderate to high angle (average $70^{\circ}$ ). The mineral body is plunge controlled, which varies from $45^{\circ}$ to $25^{\circ}$ due East. A number of parallel bands are exposed in the area due to tight isoclinals folding. These bands are thin along the limbs and thick along the trough areas. Braunite is the principal mineral associated with haussmanite, redenburgite, jacobsite etc. Veins of rhodinite and bands of gondites are also encountered during course of mining.

\section{ENGINEERING GEOLOGICAL INVESTIGATIONS}

For determining geotechnical parameters for designing the stoping parameters, engineering geological mapping in the proposed and working stope blocks was carried out. The lithological set-up between cross cuts X-2305 and X-2425 between Level-3 (270') and Level-2 (170') is given in the geological map (Fig. 1). Detailed engineering geological mapping was carried out and geotechnical parameters were collected for the length of $60.0 \mathrm{~m}$ between cross cuts X2335and X-2395 from Level-3. At this location the general strike direction of the ore body is East-West $\left(\mathrm{N} 90^{\circ} \mathrm{E}-\right.$ $\mathrm{S} 90^{\circ} \mathrm{W}$ ), and the dip varies from $62^{\circ}$ to $85^{\circ}$ due south. The ore body is being mined along the strike and dip. The hanging wall consists of mica schist and the footwall consists of quartz mica schist, whereas at some places both hanging wall and footwall are consisting of quartz mica schist due to folding. Width of ore body is not uniform and it varies from $7.0 \mathrm{~m}$ to $13.0 \mathrm{~m}$ with bulging and pinching. 


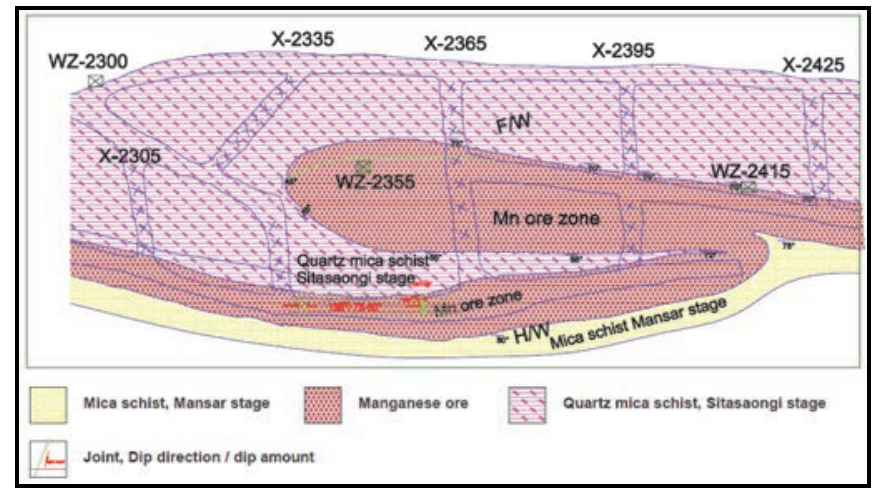

Fig.1. Geological map between cross cuts X-2305 and X-2425 showing lithological set-up

The ore body exhibits well-developed bedding or relict stratification (Fig. 2) marked by alternate bands of spessattite, rhodonite, and manganese ores. Numerous quartz veins intersect the ore body and the wall rocks. The thickness of the individual bands varies from $2 \mathrm{~cm}$ to $30 \mathrm{~cm}$. Bedding is also well developed in quartz mica schist/quartzite of Sitasaongi Formation, whereas bedding planes are extremely rare in mica schist of Mansar Formation.

Schistocity is well developed in schist of Mansar and Sitasaongi Formations throughout the area. The bedding foliation plane has a general east-west strike and steep southern dip. Lineation made up by parallel arrangement of platy and prismatic grains such as micas and hornblende, and also of the elongated grains of quartz and feldspar is commonly observed (Fig. 3). The ore is hard, and is siliceous in nature. The contact between the ore body and the mica schist is incompetent, where as the contact between the ore body with quartz mica schist is competent (Fig. 4).

The ore body occurs with contact of similar wall rocks, i.e., quartz mica schist of Sitasaongi Formation, as also with contact of different wall rocks, i.e., mica schist of Mansar Formation and quartz mica schist of Sitasaongi Formation.

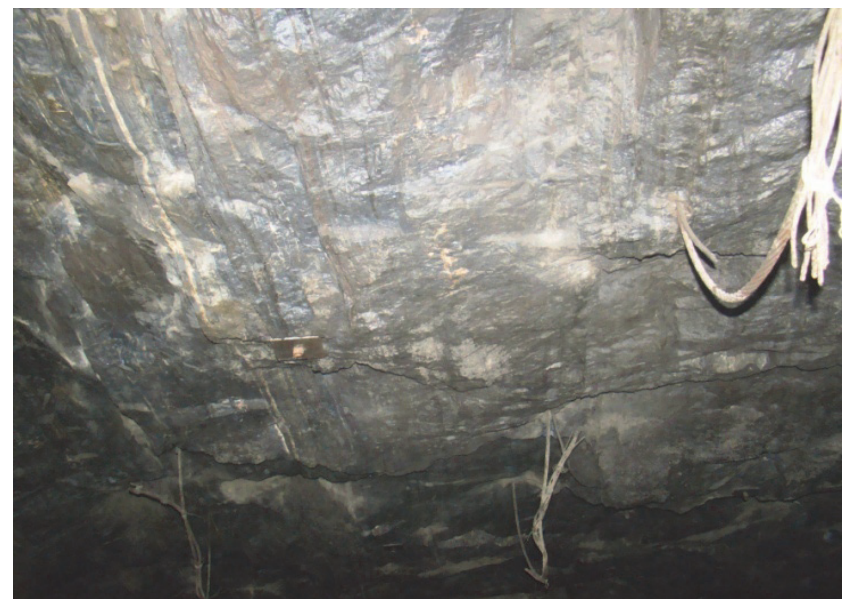

Fig.2: Banded texture (foliation) in ore zone, alternate bands of Mn-ore, mica, quartz etc.

\section{A. Physico-mechanical properties}

Block samples from the ore zone and drill cores from the Bore hole EM-37, which represent the ore body, foot wall and hanging wall were collected for determining physicomechanical properties in the laboratory. The details of the block and core samples collected from the mine is given in Table 1. Drill cores of required sizes were recovered from the block samples and all the core samples of different rock types were prepared for testing in the laboratory for physico mechanical properties as per International Society for Rock Mechanics (ISRM) suggested methods. Few photographs of the prepared and tested samples of different rock types are shown in Fig. 5a and 5b.

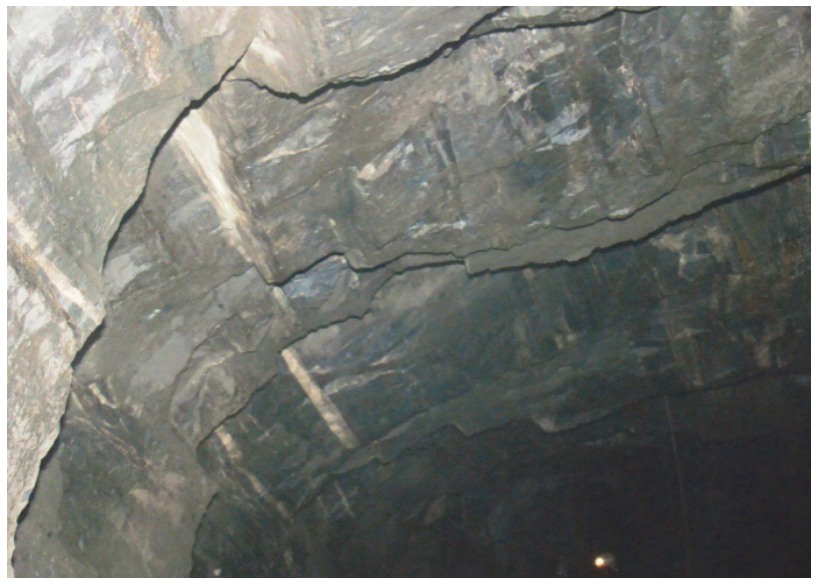

Fig.3: Lineation and bedding planes, strike parallel to ore body

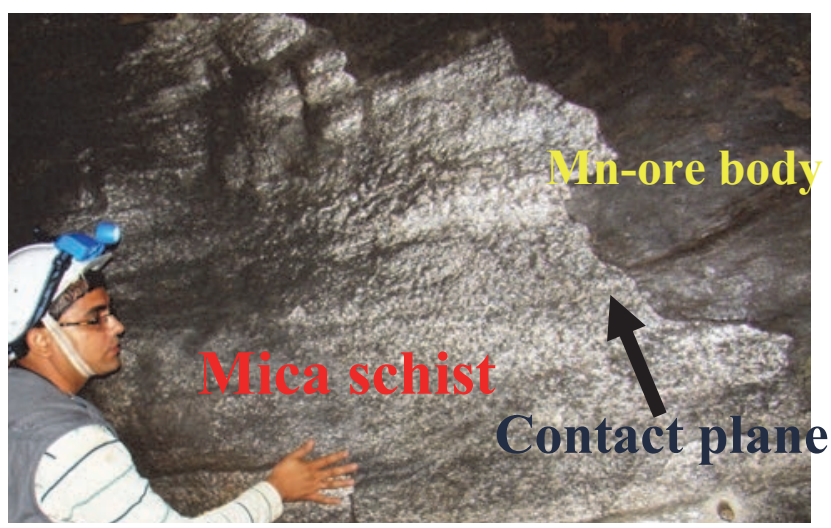

Fig.4: Contact between manganese ore body and mica schist

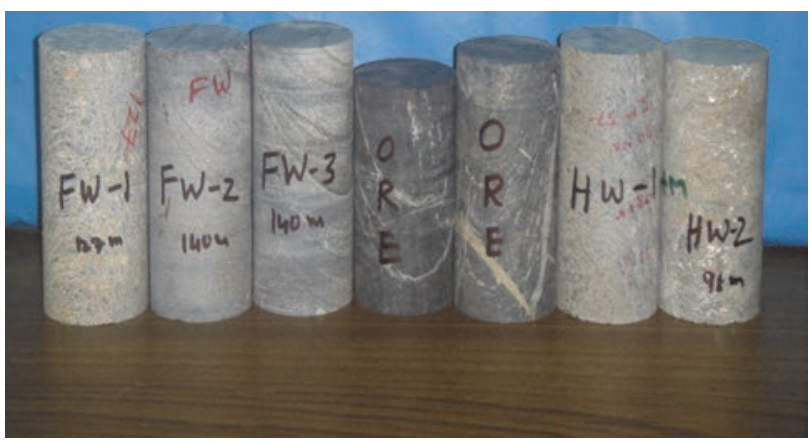

Fig.5a. Core samples prepared for testing 


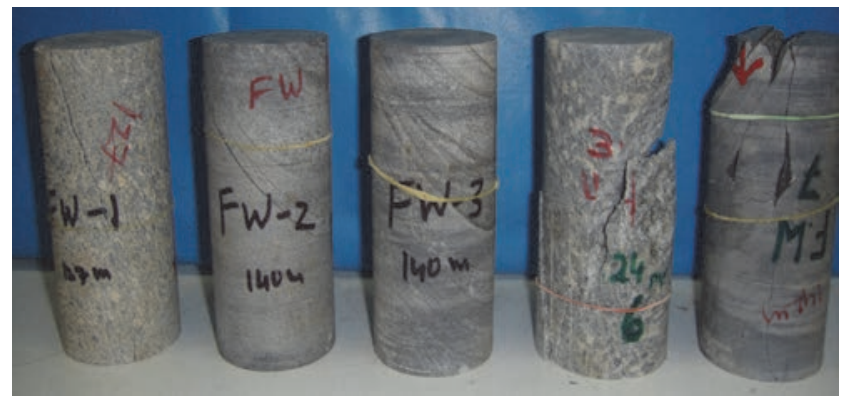

Fig.5b. Core samples after uniaxial compression (UCS) testing

TABle 1. Core Sample Details for Determination of Strength PROPERTIES

\begin{tabular}{|c|c|c|}
\hline \multicolumn{3}{|c|}{ Core samples from Bore Hole EM-37 } \\
\cline { 1 - 2 } Depth in m & \multirow{2}{*}{ Rock Type } \\
\cline { 1 - 2 } From & To & Mica schist (H/W) \\
\hline 80.00 & 100.00 & Mica schist (H/W) \\
\hline 111.00 & 116.00 & Quartz mica schist (F/W) \\
\hline 127.00 & 140.00 & Manganese ore \\
\hline 256.00 & 257.00 & Manganese ore \\
\hline 258.00 & 259.00 & Rock Type \\
\hline & Block Samples from 270' Level \\
\hline Location & MRL & Manganese ore \\
\hline CH-2335 & $181.50 \mathrm{~m}$ & Manganese ore \\
\hline CH-2345 & $181.50 \mathrm{~m}$ & Manganese ore \\
\hline CH-2363 & $181.50 \mathrm{~m}$ & Manganese ore \\
\hline CH-2365 & $181.50 \mathrm{~m}$ & Manganese ore \\
\hline CH-2485 & $176.50 \mathrm{~m}$ & Quartz mica schist (F/W) \\
\hline CH-2465 & $177.00 \mathrm{~m}$ & Quartz mica schist (F/W) \\
\hline CH-2465 & $177.00 \mathrm{~m}$ & \\
\hline
\end{tabular}

\section{B. Rockmass classification}

The rock mass classification parameters namely, rock quality designation (RQD), joint set number (Jn), joint roughness number (Jr), joint alteration number (Ja), joint water reduction factor $(\mathrm{Jw})$, stress reduction factor (SRF), Uniaxial compressive strength (UCS), spacing of discontinuities, joints conditions, orientation of discontinuities and hydrogeological conditions, were estimated for ore as well as wall rocks using 3-D geological mapping and core logging. Based on these parameters, the rock mass has been characterized using Q-system [2] and RMR system [3]. Empirical estimation of support requirement for the present case was done using the above two rockmass classification systems. The wall rocks namely foot wall and hang wall has the Q value of 22-25 and 7.58.25 respectively, and according to $\mathrm{Q}$ chart falls under 'Good' and 'Fair' categories respectively. On the other hand the estimated 'Q" value for the ore is 17-18, which comes under 'Good' category as per the Q chart.

\section{EMPIRICAL DESIGN}

Design of stoping parameters was carried out for the proposed stope block at Chikla mine taking in to consideration of the geotechnical data presented in the previous sections. As per the data, the wall rocks and the ore body have distinct rockmass characteristics. As per the Q classification, although the strength of the intact ore sample is very high, the rockmass strength of the same is not better than the footwall rock. Hangwall is the weakest and both the foot wall rock mass and the orebody fall under 'Good' category while the hangwall rock mass fall under fair category. ' $Q$ ' chart which relates the rockmass quality and the rock support is shown in Fig. 6. This chart was used to determine the support requirements for the particular Q values and the span of the excavation.

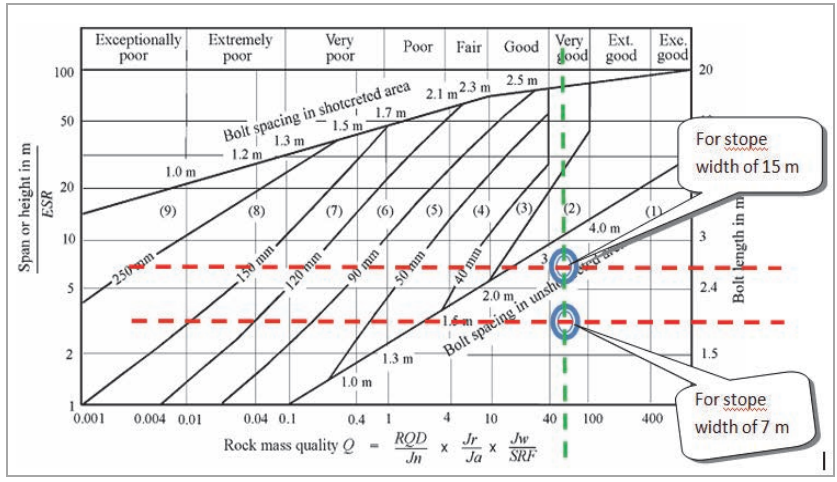

Fig.6. Rockmass classification and support as per Q chart

\section{A. Recommended support design}

Major concern in an underground hard rock mine employing open stope methods such as cut and fill is safety of personnel, equipment and dilution of the ore due to failure of surrounding rock mass. For the present case the rock mass falls under good category in case of Ore body and the relevant support system based on Q chart is presented in Fig. 6. Since the stope width varies from $7 \mathrm{~m}$ to $15 \mathrm{~m}$, the support system is recommended conservatively for the stope width of $15 \mathrm{~m}$.

As per the $\mathrm{Q}$ chart shown in Figure 6, the support requirements for a $15 \mathrm{~m}$ wide stope is systematic bolting. The spacing of the bolting works out to be between $2 \mathrm{~m}$ and $3 \mathrm{~m}$. Comparing these support requirements to the present practice at the Chikla mine concludes that the pre support of $12 \mathrm{~m}$ long cable bolts with $2 \mathrm{~m}$ spacing (square pattern) was found to be more than sufficient. However the $1.5 \mathrm{~m}$ rock bolt in between the cable bolt, as being practiced currently will not serve any purpose for the rock mass conditions present here and is not recommended for the proposed stope. They are only effective if the cable bolts are widely spaced and the rock mass are closely jointed and the blocky structure is present. The geological mapping of the area is presented in Fig.1 and it can be observed that the strata of the proposed stope area are not blocky. In the rock mechanics point of view also the intermediate rock bolts of $1.5 \mathrm{~m}$ long for the present rock mass conditions will not serve any purpose. Further it is going to be an expensive, time consuming exercise for negligible benefits. Moreover from the second round of cable bolt installation the first round of the cable bolts will also perform the job of the rock 
bolts even better as they are at least $4 \mathrm{~m}$ in length of overlapping and hence it is recommended to omit the installation of rock bolts of $1.5 \mathrm{~m}$ long in between the cable bolts.

\section{B. Stability of crown pillar}

The stability of the crown pillars can be evaluated using empirical and numerical methods. This paper deals with the evaluation of crown pillar stability using both empirical and numerical modeling design techniques. For the present case, Scaled Crown Pillar Span Concept of [4, 5], was used to evaluate the crown pillar stability. The general arrangement of crown pillar and post and rib pillars in this mine is shown in Fig.7. It can be observed that the present practice is to leave $5 \mathrm{~m}$ thick crown pillar supported by cable bolts with 2 m spacing.

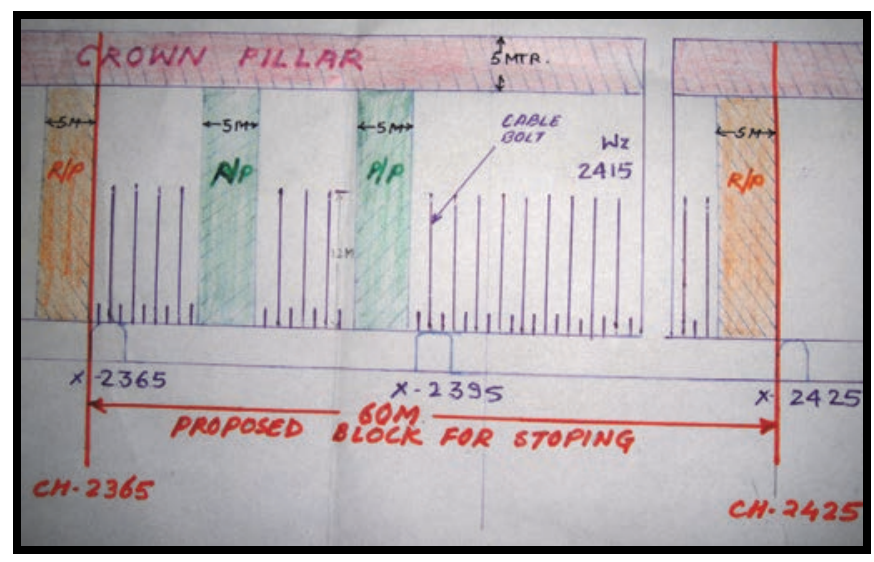

Fig.7. Arrangement of Crown pillar, Rib and post pillar in the proposed stope block

As per Carter (1992), crown pillar instability would occur if the scaled crown pillar span (Cs) is greater than the critical span $(\mathrm{Sc})$, these parameters are given below.

Scaled crown pillar span, $\mathrm{C}_{\mathrm{s}}=S \sqrt{\frac{\gamma}{T\left(1+\frac{S}{L}\right)(1-0.4 \cos \theta)}}$

where $\mathrm{S}=$ Crown pillar $\operatorname{span}(\mathrm{m})=15 \mathrm{~m}$

$\mathrm{L}=$ Crown pillar length $(\mathrm{m})=60 \mathrm{~m}$

$\mathrm{T}=$ Crown pillar thickness $(\mathrm{m})=5 \mathrm{~m}$

$\gamma=$ Specific gravity of the rock mass $=3.5$

$\theta=$ Orebody $/$ foliation $\operatorname{dip}=70^{\circ}$

Scaled crown pillar span for the present case with $15 \mathrm{~m}$ wide span and the $5 \mathrm{~m}$ thick will be: 11.2

And the critical span $\mathrm{Sc}=3.3 \times \mathrm{Q}^{0.43}$

Accordingly the critical span for the present case with Q value of 18 will be: 11.4. Clearly it can be observed that the scalled span of the crown pillar $\left(\mathrm{S}_{\mathrm{c}}\right)$ is less than the critical span $\left(C_{s}\right)$ and hence the instability of crown pillar will not occur. Also the rib and post pillars are not taken in to consideration here; with them the stability of the crown pillar will be very high. And as such there is a scope for further optimisation of rib and post pillars.

\section{NUMERICAL MODELING}

With a view to ascertain the effectiveness of the cable bolts and the stability of crown pillar, rib and post pillars, a 2Dimensional numerical modeling is performed. This modeling is also aimed to confirm the empirical design results. For this purpose two different models were created. First model (Model-1) is created to ascertain the efficacy of the cable bolts and the crown pillar stability. The model geometry for this is shown in Fig. 8. The second model (Model-2) which was created to study the behaviour of the rib and post pillars along with crown pillar. The model geometry for this is shown in Fig. 9. The stope cross section at the maximum width is taken in to consideration for Model-1. On the other hand, longitudinal section (Fig. 9), of the proposed stope block including rib and post pillars was considered for Model-2.

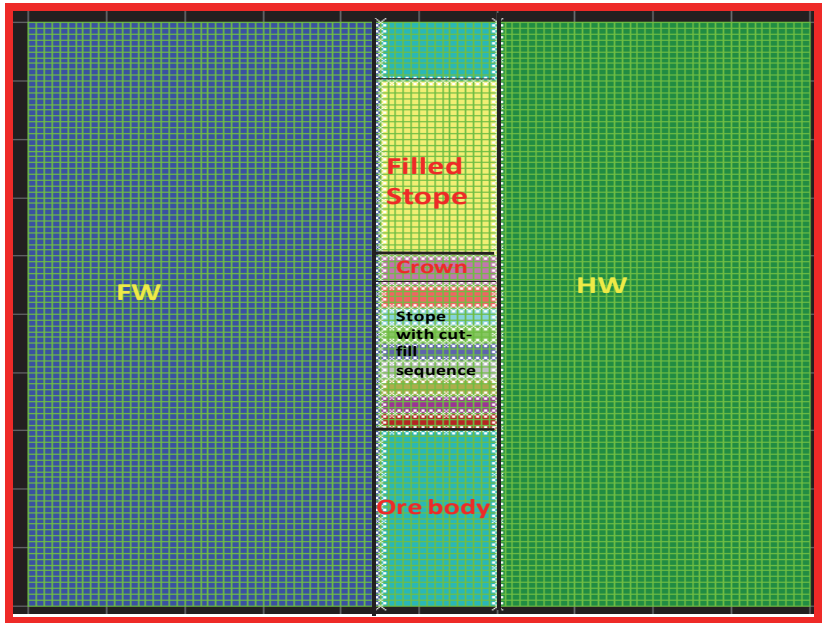

Fig. 8. Model geometry for Model-1

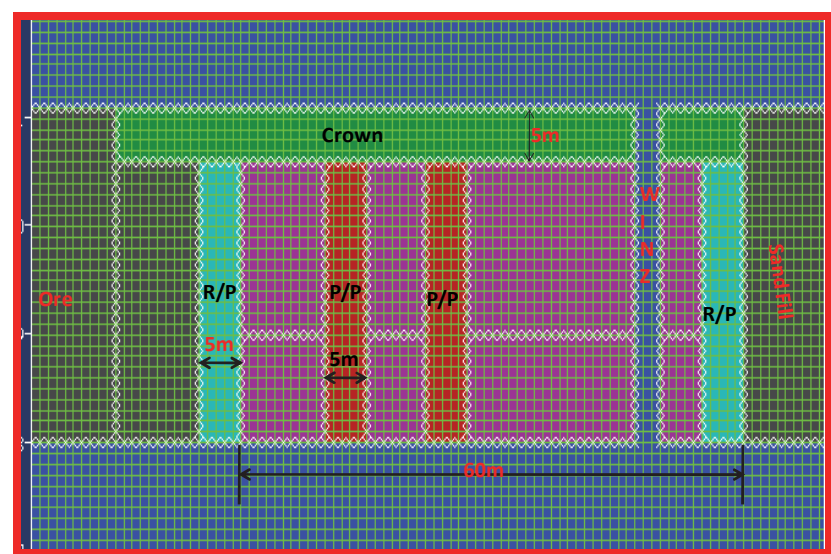

Fig. 9. Model geometry for Model-2

As explained above, model-1 is created to study the efficacy of the cable bolt support without any rock bolts in between. It also aimed to examine the stability of the crown pillar when the entire stope is excavated and the back fill is in place. Although the width of the ore body varies from $7 \mathrm{~m}$ to $15 \mathrm{~m}$, to be on conservative side maximum width of the stope is considered for the modeling purpose. All the material properties for the model are taken from the test 
data. For the purpose of insitu stress conditions, vertical loading was calculated for vertical stresses and the horizontal stresses were taken as twice the vertical stresses. The cut and fill sequence as practiced in the mine is simulated. Cable bolts of $12 \mathrm{~m}$ long are installed with $2 \mathrm{~m}$ spacing and the overlapping as practiced in the Mine.

It was observed from the model results, that the cable bolts are lightly loaded and none of the bolts yielded after nearly half of the stope is mined out. Also the significant deformations or instability of the roof was not observed and are stable. This model results suggest that the cable bolts at $2 \mathrm{~m}$ spacing is efficient in controlling the back and thus not allowing any instability. However it is worth to mention here that this model does not take in to account the blasting effects. It can also be observed that the designed crown pillar is highly safe and stable with the cable bolt supports after full excavation and the cable bolts are lightly loaded and have enough strength to accommodate any unforeseen loads coming on to the crown pillar.

To study the stability and requirement of the proposed rib and post pillars, a longitudinal section as shown in Fig. 9. was considered in this model. All other material properties and insitu conditions are same as in the Model-1. Stress distribution on post pillars and rib pillars after full stope excavation is studied. It was observed that the post pillars and the rib pillars are lightly loaded and have not yielded. The stability of the pillars will be enhanced with the back fill in place. However it is important to mention here that the two dimensional (2D) model could not truly represent the present geometry.

It was further attempted to examine the stability of the stope without rib pillars and re arranging the post pillars as shown in Fig.10, while keeping all other parameters as in the earlier models. It was observed from the results that the stress distribution on to the post pillars is not causing any instability and is stable. The stability of the post pillar enhances with the back fill. In light of this and as such the rib pillars are more or less damaged during the stoping operation, due to which they are not fully carrying the load in practice, this model result suggests that the rib pillars can be eliminated and the post pillars of $5 \mathrm{mx} 5 \mathrm{~m}$ sizes may be left in situ in the proposed stope block.

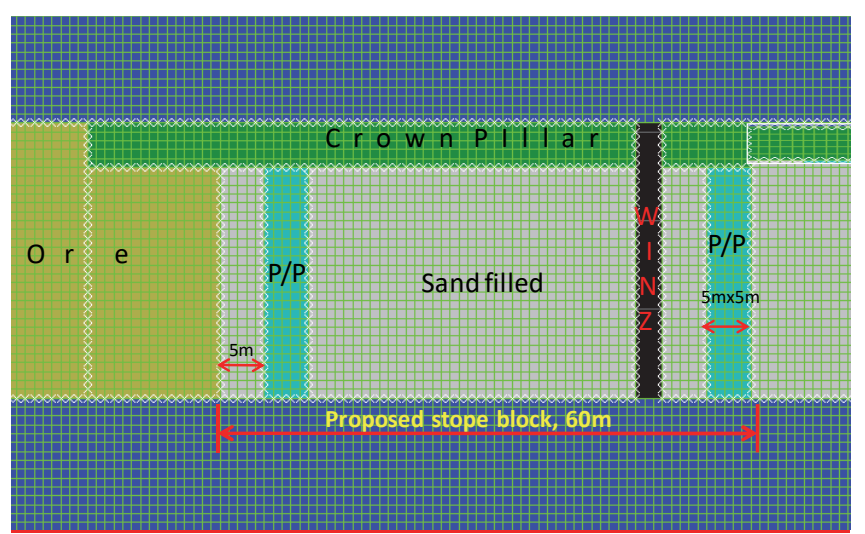

Fig. 10. Model geometry for proposed post pillars without rib pillars

\section{CONCLUSIONS AND RECOMMENDATIONS}

Support requirements for the proposed stope block between $\mathrm{CH}-2365$ and $\mathrm{CH}-2425$ from level 3 to level 2 is evaluated through the empirical methods and the stability of the crown pillar and the support behaviour is studied with numerical modeling and presented in this paper. It was found that the wall rocks and the ore body have distinct strength properties and the rock mass falls in to good and fair categories. Two most popular rock mass classification systems were used for estimating the support requirements for the proposed stope block. A two dimensional finite deference code was used for numerical modeling. Following conclusion can be drawn from the above study.

- AAs per the detailed empirical design, pre support of the stope with the $12 \mathrm{~m}$ long cable bolt support with $2 \mathrm{~m}$ spacing is recommended as is the present practice.

- IIt was found from the empirical methods and from the field geological mapping that the $1.5 \mathrm{~m}$ long rock bolts in between the cable bolts, which is the present practice, is not recommended for the proposed block and hence the recommended support system is only cable bolts without any rock bolts in between

- 22D numerical modeling results also confirm the efficacy of the cable bolt support system, without any rock bolts in between cable bolts.

- Requirement and the stability of the crown pillar is assessed for the proposed block using empirical methods, and it was found that the $5 \mathrm{~m}$ thick crown pillar is a highly conservative estimate even with FOS of 1.5.

- 22D numerical modeling of a cross section of the proposed stope also confirms the stability of the crown pillar along with the cable bolts. However to reduce the thickness as found in empirical method, it is suggested that the present crown pillar should be instrumented and monitored to better understand its behaviour during and after the mining operations. Based on the monitoring results, coupled with 3D numerical modeling, future stopes could be optimized.

- AAlso, further optimisation or elimination of rib pillar was examined using 2D numerical model. The results suggest that the rib pillar can be eliminated and the post pillars of $5 \mathrm{~m} \times 5 \mathrm{~m}$ may be left in situ for ore body wider than $12 \mathrm{~m}$, as shown in the Figure 10 .

- IIt is also recommended that the post pillars and the crown pillar should be instrumented and the behaviour should be monitored both during and after the stoping operations. This will enable us to understand the behaviour and stability of the proposed structures. 


\section{ACKNOWLEDGEMENTS}

We are thankful to the MOIL Ltd, Nagpur, particularly The Chairman and Managing Director (CMD), Director(P\&P) and Mr. G. Manaekar, Dy. GM for sponsoring this project. And all the concerned officers of Chikla mine, for extending their support and cooperation for the successful completion of the project. We are extremely grateful to the Director, NIRM for his encouragement and advice throughout this project. We are also thankful to $\mathrm{Mr}$. S Udaya Kumar, Scientist of NIRM for his cooperation and timely conducting the rock testing for Physico mechanical properties .The services of Sri Prabhu and Sri Vinod of NIRM is also acknowledged.

\section{REFERENCES}

[1] M.R.Shaharan, J.C.Jhanwar, R.More, B.K.Jha and A.K. Chakravarthy, "optimisation of rock reinforcement systems for cutand-fill stopes of chikla mine, MOIL Ltd," Un published report submitted to MOIL Itd by CMRI, Nagpur, 2006.

[2] N.R. Barton, R. Lien and J. Lunde, "engineering classification of rock masses for the design of tunnel supports" Rock Mech. Vol.6.189-239.

[3] Z.T. Bieniawski, “Engineering rock mass classification”, John Wiely \& Sons,1 Pennsylvania, 1989, pp. 29-90

[4] T.G.Carter, "A new approach to surface crown pillar design," proceedings of $16^{\text {th }}$ Can.Rock Mechanics symposium, Sudbury,1992, pp. 75-83.

[5] T.G.Carter and R.I. Miller, "Crown pillar risk assesment- cost effective measures for mine closure remediation planning". Trans. Inst. MinMetl. Vol 104, 1995, pp. A41-A57. 